\title{
Ruminant grassland production systems in Ireland
}

\author{
M. O’Donovan ${ }^{1 \dagger}$, D. Hennessy ${ }^{1}$, P. Creighton ${ }^{2}$ \\ ${ }^{1}$ Teagasc, Animal and Grassland Innovation Centre, Moorepark, Fermoy, Co. Cork, Ireland \\ ${ }^{2}$ Teagasc, Animal and Grassland Innovation Centre, Athenry, Co. Galway, Ireland
}

Abstract

In Ireland grazing systems provide the basis of sustainable livestock production, as grazed grass is the cheapest feed source of nutrients for ruminants. The main future objective for these systems is to achieve high grass utilisation, ensure system sustainability and maintain extremely high animal health and welfare. There is no reason why all three cannot be combined. Ireland's national farm policy targets growth in exports to €19 billion per annum by 2025. This figure represents an $85 \%$ increase from the current $3 \mathrm{yr}$ average. There are major improvements required in the areas of grassland management and its conversion into milk and meat to fulfil such a target. While every farm situation is unique due to varying soil types, climatic conditions, stocking rates and management capabilities, herbage production and utilisation is below optimum on most farms. Irish farms, especially dairy farms, are expanding and will continue to do so over the next number of years. Increasing stocking rates and more compact calving and lambing has resulted in increased spring feed demand. Extra grass needs be grown and utilised in this period to minimise the use of supplementary feed. This paper outlines the importance of grassland on Irish farms, and where farms can improve grassland management, to increase output, lower farm costs and improve further farm system sustainability.

Keywords

Grassland $\cdot$ grazing $\cdot$ ruminant production $\bullet$ sustainability

\section{Introduction}

Grasslands contribute substantially to Irish agricultural production systems providing a large proportion of the feed requirements of ruminant livestock (O'Mara, 2008). Grassland in Ireland accounts for approximately 92\% (3.91 million hectares [ha]) of the agricultural land area (CSO, 2017) (Table 1). Rough grazing includes grazed unreclaimable bogland, and grazed mountain and lowland partially covered in scrub, bushes or rock (O'Mara, 2008). The average proportion of the total grass silage area (1.066 million ha) harvested for first, second and subsequent silage harvests is $78 \%, 21 \%$ and $1 \%$, respectively (O'Donovan et al., 2011). The use of other crops, such as maize silage and beet, has declined in recent years. Irish grassland can produce some of the highest non-irrigated herbage yields (12-16 t dry matter (DM)/ha per annum) in Europe (O'Donovan et al., 2011).

Table 2 shows livestock numbers in Ireland for the period 2013-2017. Total cattle numbers have increased by 461,000 head. The substantial increase in this number has been generated from the increase in dairy cows $(+269,000)$; suckler cows numbers have decreased $(-69,000)$ in the same period. Increases in younger stock have taken place in line with the maternal increases of dairy cows. Total sheep numbers have increased by 245,900 in the period; however, the number of breeding ewes has declined by 57,000 , which shows an increase in the efficiency of the sheep flock.

The increase in dairy cow numbers has been greatest in the South East and West of the country, which have seen the largest regional increases (+70,000 each); the Western and Border regions have recorded the least increase, 11,000 and 17,000 , respectively. The largest reduction in suckler cow numbers has occurred in the South East $(-15,000)$, while suckler cow numbers in the West of Ireland have remained largely the same. In the future, it is likely that suckler cow numbers will decline further, and in 2017 the number of suckler cows calved declined by $3 \%$. 
Table 1: Area farmed ('000 ha) by type of land use and year (2013-2017)

\begin{tabular}{|c|c|c|c|c|c|}
\hline & 2013 & 2014 & 2015 & 2016 & 2017 \\
\hline Area farmed (AAU $\left.{ }^{1}\right)$ & $4,477.8$ & $4,465.8$ & $4,429.5$ & $4,447.2$ & $4,489.5$ \\
\hline Crops and pasture & $4,004.3$ & $3,971.5$ & $3,926.0$ & $3,914.8$ & $3,969.3$ \\
\hline Pasture & $2,337.7$ & $2,308.4$ & $2,299.4$ & $2,307.8$ & $2,322.7$ \\
\hline Hay & 218.4 & 217.9 & 195.7 & 188.4 & 192.1 \\
\hline Grass silage & $1,071.0$ & $1,077.6$ & $1,071.1$ & $1,066.8$ & $1,088.9$ \\
\hline Maize silage & 14.5 & 13.9 & 12.9 & 10.9 & 11.9 \\
\hline Fodder rape and kale & 1.4 & 1.2 & 1.7 & 1.6 & 1.6 \\
\hline Beet & 10.1 & 10.3 & 9.6 & 9.5 & 10.0 \\
\hline Other crops & 4.7 & 4.0 & 5.8 & 7.7 & 28.1 \\
\hline Total cereals & 307.8 & 306.7 & 292.4 & 281.1 & 272.4 \\
\hline Rough grazing in use & 473.5 & 494.2 & 503.6 & 532.4 & 520.2 \\
\hline
\end{tabular}

${ }^{1} \mathrm{AAU}=$ Agricultural Area Utilised. Source: Central Statistics Office (2017).

Table 2: Number of livestock ('000 head) by type of animal and year (2013-2017)

\begin{tabular}{|c|c|c|c|c|c|}
\hline & 2013 & 2014 & 2015 & 2016 & 2017 \\
\hline Total cattle & $6,902.6$ & $6,926.1$ & $6,963.5$ & $7,221.2$ & $7,363.5$ \\
\hline Cows & $2,313.5$ & $2,355.4$ & $2,371.6$ & $2,501.6$ & $2,513.6$ \\
\hline Dairy cows & $1,163.2$ & $1,226.4$ & $1,295.8$ & $1,397.9$ & $1,432.7$ \\
\hline Suckler cows & $1,150.3$ & $1,129.0$ & $1,075.8$ & $1,103.7$ & $1,081.0$ \\
\hline Bulls & 41.4 & 40.8 & 36.5 & 25.0 & 16.9 \\
\hline Cattle: 2 yr and over & 768.3 & 884.3 & 808.1 & 715.5 & 788.1 \\
\hline Cattle: $1-2$ yr & $1,811.0$ & $1,767.2$ & $1,705.1$ & $1,853.3$ & $1,913.9$ \\
\hline Cattle: under $1 \mathrm{yr}$ & $1,968.5$ & $1,878.4$ & $2,042.2$ & $2,125.9$ & $2,130.9$ \\
\hline Total sheep & $5,007.0$ & $5,096.8$ & $5,138.7$ & $5,179.2$ & $5,252.9$ \\
\hline Breeding sheep & $2,648.6$ & $2,591.3$ & $2,563.9$ & $2,582.8$ & $2,591.5$ \\
\hline
\end{tabular}

\section{Feed costs}

Grazed grass is the most efficient feed for grass-based ruminant production systems in Ireland. The relative cost of grazed grass is $€ 75 / t$ utilisable (U) DM compared to first cut grass silage at $€ 185 / t$ UDM, second cut grass silage at $€ 182 / t$ UDM and rolled barley at $€ 188 / t$ UDM (Finneran et al., 2010). Costs were calculated using a stocking rate of 2.5 livestock units (LU)/ha and herbage DM production of $13.5 \mathrm{t} \mathrm{DM} / \mathrm{ha}$ and a land costs charge of $€ 350 /$ ha (Finneran et al., 2010) and feeds were compared on a UFL basis. The relative competitive advantage of grazed grass is expected to increase over the next number of years due to higher concentrate prices and the high cost of producing conserved feeds (grass and maize silage; costs include labour, energy and machinery costs).

\section{Industry targets}

The progress of the Irish ruminant sector has been assisted greatly by the positive Agriculture Policy of the Irish Department of Agriculture, Food and Marine. Successive Agriculture Policy initiatives such as Food Harvest 2020 and currently Food Wise 2025 (DAFM, 2015) have identified agriculture as a key sector for the growth of the Irish economy. The Food Wise 2025 report (DAFM, 2015) has identified both herbage DM production and utilisation targets for Irish dairy production systems. In 2016 the gross agricultural output 
was valued at $€ 6.92$ billion (DAFM, 2016). In 2016, dairy and ingredients exports increased by $2 \%$ to $€ 3.38$ billion. The value of the beef industry to the economy is currently in excess of $€ 2.38$ billion. Annual beef output exceeds $535,000 \mathrm{t}$, of which $90 \%$ is exported. Sheep production is a significant contributor to the agricultural economy producing $61,000 t$ of sheep meat with an output value of $€ 240$ million in 2016 . This is an increase in value of $4 \%$ compared to 2015 , with a meat volume output increase of $3 \%$. The 36,313 sheep flocks produce a high-quality product with about $75-80 \%$ exported. Since 2010, international markets have accounted for half of the growth in total exports, which reflects the industry's ability to identify and develop new business opportunities. Irish food and drink exports to China have increased six-fold in 6 years, while exports to North America and the rest of Asia have doubled in the same period.

Every 3 yr sectorial enterprise roadmaps (Table 3) are developed for the main ruminant industries (dairy, beef and sheep). These roadmaps are very important targets for the sectors and act as guides to the industry. With the current expansion of the dairy milk pool, systems of milk production in Ireland can become more efficient through increased dairy cow fertility and better grass utilisation, that is, more effective use of home grown feed. There is an expectation of and commitment from the industry to expand in a sustainable manner, which is underpinned by agricultural research in Ireland. In suckler beef production reduced calving interval and increased herbage DM utilisation (more grass in the diet) will together improve the efficiency of the sector. In the sheep sector the key efficiency gains will come from increasing the number of lambs reared per ewe, increasing stocking rate and finally maximising the use of grass and reducing the reliance on supplementary feeds. The common efficiency to be achieved across all sectors is increased grass utilisation.

\section{Farm system sustainability}

Farm system sustainability is achieved under the three pillars of economic, social and environmental sustainability. Grass-based systems are more resource efficient as they use home grown feed stuffs and minimise the requirements for purchased feedstuffs and therefore the resources (land, labour, energy, machinery) associated with those feedstuffs. One of the key challenges facing agriculture today in Ireland, and in Europe, is centred on the requirement to reduce environmental losses and impacts. In Ireland and Western Europe, grassland has a high capacity to capture nitrogen $(\mathrm{N})$ as grass is present year-round and grass is actively growing for a large part (10-12 mo) of the year.

Future grass-based milk and meat production systems will need to minimise nutrient losses (e.g. $\mathrm{N}$ and phosphorus $[\mathrm{P}]$ )
Table 3: Dairy, suckler beef and sheep sector roadmaps for current performance, future performance targets up to 2025 and research targets

\begin{tabular}{|c|c|c|c|}
\hline & Current & $\begin{array}{c}2025 \\
\text { target }\end{array}$ & $\begin{array}{c}\text { Current } \\
\text { research } \\
\text { target } \\
2025\end{array}$ \\
\hline \multicolumn{4}{|l|}{ Dairy sector } \\
\hline Milk delivered (kg/cow) & 5,036 & 5,739 & 5,800 \\
\hline $\begin{array}{l}\text { MS (fat + protein) } \\
\text { delivered (kg/cow) }\end{array}$ & 372 & 448 & 475 \\
\hline Calving interval (d) & 394 & 385 & 365 \\
\hline Stocking rate (LU/ha) & 1.96 & 2.15 & 2.94 \\
\hline Herbage utilised (t DM/ha) & 7.36 & 10.0 & 12.7 \\
\hline Concentrate per cow (kg) & 1,008 & 750 & 400 \\
\hline Nitrogen fertiliser (kg N/ha) & 176 & 230 & 250 \\
\hline \multicolumn{4}{|l|}{ (kg CO $2 \mathrm{e} / \mathrm{kg} \mathrm{MS}$ ) } \\
\hline \multicolumn{4}{|l|}{ Suckler beef sector } \\
\hline Calves/cow per year & 0.81 & 0.85 & 0.95 \\
\hline Calving interval (d) & 407 & 397 & 365 \\
\hline Herbage utilised (t DM/ha) & 5.6 & 6.2 & 11.3 \\
\hline Concentrate per LU (kg) & 393 & 390 & 298 \\
\hline Nitrogen fertiliser (kg N/ha) & 129 & 145 & 210 \\
\hline $\begin{array}{l}\text { Greenhouse gas emissions } \\
\text { (kg CO} 2 \mathrm{e} / \mathrm{kg} \text { carcass) }\end{array}$ & 25.7 & 23.5 & 21.8 \\
\hline \multicolumn{4}{|l|}{ Sheep sector } \\
\hline $\begin{array}{l}\text { Lambs weaned/ewe per } \\
\text { year }\end{array}$ & 1.29 & 1.45 & 1.75 \\
\hline Stocking rate (ewe/ha) & 7.3 & 9 & 12 \\
\hline Concentrate input (kg/ewe) & 90 & 50 & 35 \\
\hline $\begin{array}{l}\text { Lambs drafted by October } \\
1(\%)\end{array}$ & 71 & 70 & 65 \\
\hline Nitrogen fertiliser (kg N/ha) & 69 & 99 & 132 \\
\hline
\end{tabular}

Source: Teagasc (2016a).

to water and gaseous emissions (greenhouse gas [GHG], ammonia) to the atmosphere, so that production systems operate in an acceptable way to society as a whole (i.e. good animal welfare, preservation of the ecosystem, landscape, biodiversity). In 2015, nationally $\mathrm{N}$ fertiliser application was $129 \mathrm{~kg} / \mathrm{ha}$ and $39 \mathrm{~kg} / \mathrm{ha}$ on dairy and beef farms, respectively, and an average of $63 \mathrm{~kg} \mathrm{~N} / \mathrm{ha}$ for all agricultural enterprises including tillage (Wall \& Dillon, 2017). Inputs of $P$ fertiliser were $4 \mathrm{~kg} / \mathrm{ha}$ and $9 \mathrm{~kg} / \mathrm{ha}$ and potassium (K) fertiliser were $9 \mathrm{~kg} / \mathrm{ha}$ and $21 \mathrm{~kg} / \mathrm{ha}$ for beef and dairy farms, respectively, in 2015; 
these levels of $\mathrm{P}$ and $\mathrm{K}$ are not adequate for maintenance levels. There has been a continual decline in fertiliser $\mathrm{N}$ input since 2005 (average $82 \mathrm{~kg} / \mathrm{ha}$ ) to date. From this analysis it is clear that Irish livestock farms are low chemical fertiliser input systems and in fact are not applying enough $\mathrm{P}$ and $\mathrm{K}$ to maintain adequate fertility levels. Soil $\mathrm{pH}$ levels are well off the requirements for even reasonable levels of grassland output. The most recent research (O'Brien et al., 2017) shows that on National Farm Survey (NFS) farms, the average carbon footprint of milk from Irish farms decreased from 1.17 to 1.04 of carbon dioxide $\left(\mathrm{CO}_{2}\right)$-equivalent $/ \mathrm{kg}$ of fat and protein corrected milk from 2013 to 2015 . This reduction in the average footprint was largely due to an increase in milk solids (MS) yield per ha and a decline in concentrate feeding. This led to a reduction in animal enteric methane emissions, and $\mathrm{CO}_{2}$ and nitrous oxide emissions from feed production.

On farm $\mathrm{N}$ use efficiency (NUE) can be improved substantially. Recent Teagasc National Farm Survey (NFS) reports have shown that NUE is, on average, approximately $25 \%$ (Buckley et al., 2019). Some of this lower NUE is due to high levels of concentrate feeding and low MS levels produced from farms. Recent research work from McAuliffe (2020) has shown NUE closer to $40 \%$ as a result of the inclusion of white clover in grazed swards and higher MS output per ha from grass-white clover systems compared to grass-only swards combined with low concentrate supplementation levels. Increased white clover inclusion is important to increase NUE on Irish farms in the future, as are better slurry management and the use of low emission slurry systems. Improving NUE will come from a number of combined sources, better fertiliser use, reducing $\mathrm{N}$ surplus, better slurry usage, the use of grass white clover swards, lower concentrate usage and the use of lower crude protein concentrates at pasture.

The production system must be profitable, afford a good work-life balance with family life and provide a good working environment for the farmers and any staff that are directly employed in the business.

\section{Increased demand for grass on farms}

Major improvements are required in grazing management and the conversion of grass into milk and meat products. While every farm situation is unique with varying soil types, local climatic conditions, stocking rates and farmer management capabilities, herbage DM production is below optimum on most farms. Irish dairy farms have expanded rapidly over the last number of years; average herd size is now approximately 82 cows per farm. Increased herd size requires additional herbage supply (i.e. grass growth) to meet an increasing herd demand. Increasing stocking rates (an additional 100,000 cows calved in spring 2016; ICBF, 2016) and compactness of calving (a reduction in mean calving date of $5 \mathrm{~d}$ and an improvement in 6-wk calving rate of 6\% from 2011 to 2015; ICBF, 2016) (Figure 1) has increased spring feed demand on dairy farms. Increases in ewe stocking rate $(+4 \%)$ and weaning rate $(+8 \%)$ and a resultant increase in carcass output per ha $(+15 \%)$ relative to the $5 \mathrm{yr}$ average, as shown in Table 4 , is also increasing the demand for grass on Irish sheep farms. Extra grass must be grown and utilised in spring to avoid increases in supplementary feed use. It is clear from financial evaluations via Teagasc profit monitor results that farms targeting high levels of grass utilisation are more profitable $(+€ 171 /$ ha, higher net profit dairy farms, $+€ 105 /$ ha on drystock farms) compared to farmers with poorer levels of grass utilisation. Higher levels of supplementary feed use is also less nutrient efficient, resulting in higher levels of $\mathrm{N}$ imported and more feed substitution.

\section{Herbage DM production on Irish farms - PastureBase Ireland data (2013-17)}

There is huge variation in grass DM production on farms. This is one of the key findings emerging from the analyses of data captured in PastureBase Ireland (www.pasturebaselreland.ie;
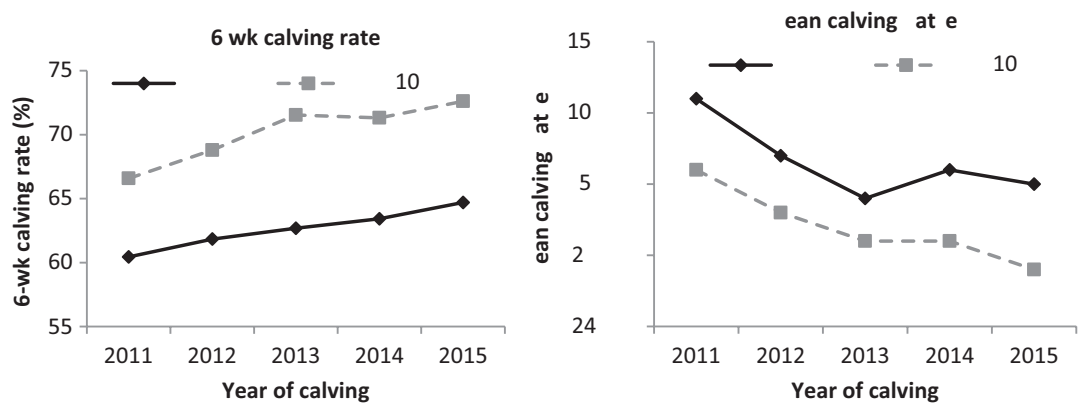

Figure 1. Trends for mean calving date and 6-wk calving rate for cows in the top $10 \%$ (broken grey line) and national average (solid black line) Economic Breeding Index (EBI). 
Table 4: National farm survey technical performance indicators on Irish sheep farms 2011-2016

\begin{tabular}{lcccccc}
\hline & $\mathbf{2 0 1 1}$ & $\mathbf{2 0 1 2}$ & $\mathbf{2 0 1 3}$ & $\mathbf{2 0 1 4}$ & $\mathbf{2 0 1 5}$ & $\mathbf{2 0 1 6}$ \\
\hline $\begin{array}{l}\text { Stocking rate } \\
\text { (ewes/ha) }\end{array}$ & 7.2 & 7.2 & 7.5 & 7.6 & 7.4 & 7.7 \\
$\begin{array}{l}\text { Weaning rate } \\
\text { (lambs/ha) }\end{array}$ & 1.3 & 1.2 & 1.3 & 1.3 & 1.3 & 1.4 \\
$\begin{array}{l}\text { Lamb carcass } \\
\text { (kg/ha) }\end{array}$ & 187 & 175 & 189 & 202 & 193 & 217 \\
\hline
\end{tabular}

Source: Teagasc (2016b).

Hanrahan et al., 2017). There are many reasons for this, including differences in stocking rate, soil fertility and grazing management practices. If soil fertility and grazing management can be improved, many farms are very capable of increasing their herbage DM production. High herbage DM production can be achieved on dairy and drystock farms, irrespective of location, through good grazing management, soil fertility management, good grazing infrastructure, and use of perennial ryegrass + white clover swards.

Figures 2 and 3 show annual DM production data from dairy and drystock farms across Ireland in 2016. These farmers have recorded $>30$ weekly farm walks (weekly assessment and recording of herbage mass present on all paddocks on the farm). In 2013, these farms produced an average of $12.2 \mathrm{t} \mathrm{DM} / \mathrm{ha}$. This increased to $13.5 \mathrm{t} \mathrm{DM} / \mathrm{ha}$ in 2014 , highlighting the year effect on grass growth. The variation between farms is very high; the difference between the lowest and highest producing farms was $9.4 \mathrm{t} \mathrm{DM} / \mathrm{ha}$. An important aspect of the herbage DM production data is that the highest producing farms are growing $>16.0 \mathrm{t} D M /$ ha, with little variation between paddocks. The lower producing farms have much greater variation between individual paddocks. In 2015 , there was an increase of $0.6 \mathrm{t} \mathrm{DM} /$ ha compared to the previous year; on average dairy farms grew $14.1 \mathrm{t} \mathrm{DM} / \mathrm{ha}$. Much of the extra herbage produced in 2015 was grown by April, and the mid-year grass growth profile was consistent

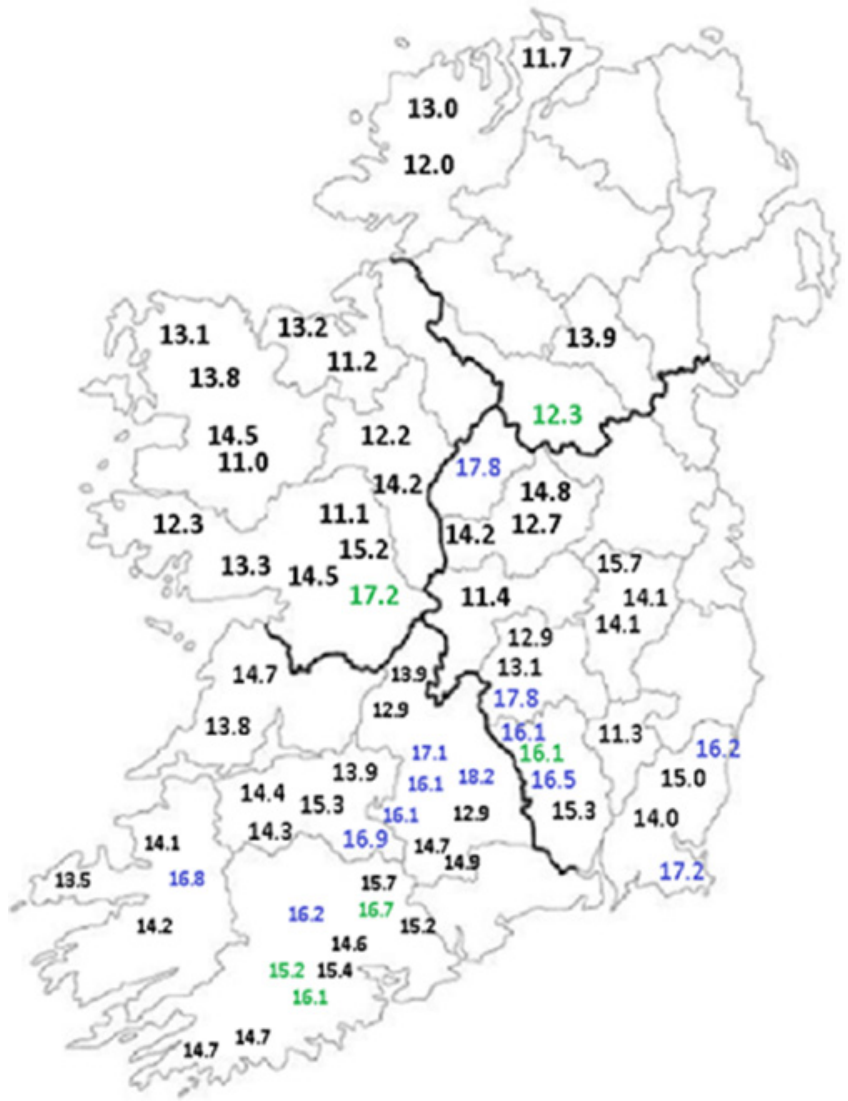

Figure 2. Grass DM production (t DM/ha) from PastureBase Ireland dairy farms across the country in 2016.

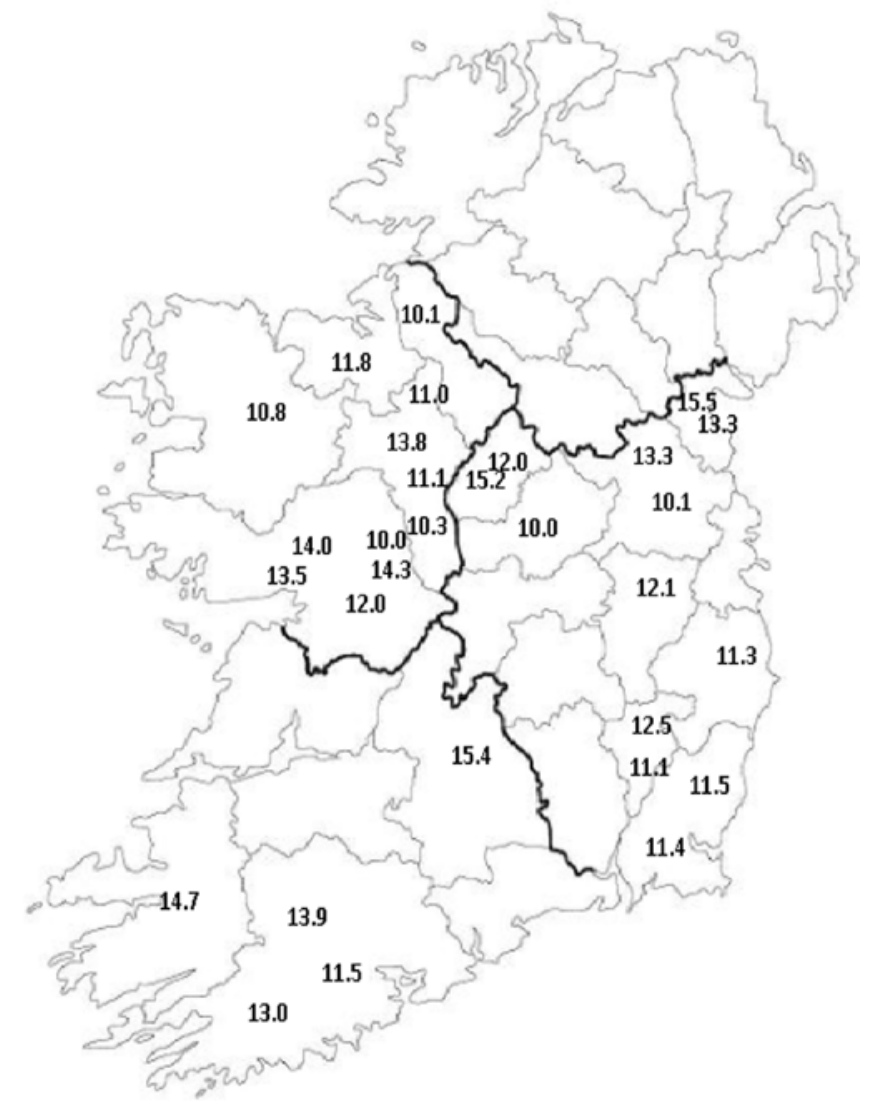

Figure 3. Grass DM production (t DM/ha) from PastureBase Ireland drystock farms across the country in 2016. 
with 2014. After a period of slow grass growth in spring 2016, growth recovered well in May, however, there was $0.3 \mathrm{t} \mathrm{DM/}$ ha reduction in DM production with the average dairy farm producing $13.8 \mathrm{t} \mathrm{DM/ha.}$

Increased herbage DM production is necessary to meet the increased feed demand on farms as stocking rate increases. Increases in stocking rate have occurred predominantly on dairy farms, and to a lesser extent on intensive beef and sheep farms. The optimum stocking rate for an individual farm is that which gives sustainable profitability and is dependent on the individual farm's grass growth capability. Another way of describing stocking rate is livestock carrying capacity. The livestock carrying capacity is the amount of forage available for grazing animals based on total annual production. The livestock carrying capacity is the maximum stocking rate possible, depending on livestock type/weight and nutrient requirements. Many Irish farms are only achieving $50-60 \%$ of their grass growth potential. Research studies looking at the effect of increasing stocking rate on herbage DM production and utilization within both dairy (McCarthy et al., 2012) and sheep systems (Earle et al., 2017) show great potential to increase farm productivity and demonstrate that dairy and drystock systems are equally capable of growing and utilising increased levels of grass at farm level. A recent survey of high performing grassland farmers found that they all agreed that they were completing more farm walks (industry target -30 grassland measurements per year), grazing their cows to lower post grazing heights (industry target $-4.0 \mathrm{~cm}$ ) and reseeding more than they were $5 \mathrm{yr}$ ago. This shows that continuous improvement in grazing management practice can result in increased herbage DM production.

\section{Increase in stocking rate}

Irish dairy farmers are growing $9.1 \mathrm{t} \mathrm{DM/ha} \mathrm{(McEvoy} \mathrm{et} \mathrm{al.,}$ 2011) and have a 220-d grazing season. Drystock farmers that are measuring grass routinely are growing $12.2 \mathrm{t} \mathrm{DM} / \mathrm{ha}$ (O'Donovan et al., 2016). The bottom $20 \%$ farms recording grass measurements into PastureBase Ireland are growing $11.0 \mathrm{t} \mathrm{DM} / \mathrm{ha}$, the average PastureBase Ireland farm is growing $13.8 \mathrm{t} \mathrm{DM} / \mathrm{ha}$, while the top $20 \%$ of PastureBase Ireland farms are growing $16.7 \mathrm{t} \mathrm{DM} / \mathrm{ha}$ (Figure 4). The variation in seasonal herbage DM production on PastureBase Ireland farms is as follows: $816-1,199 \mathrm{~kg} \mathrm{DM} / \mathrm{ha}$ in spring (January to 10 April), 4,462-4,932 $\mathrm{kg} \mathrm{DM} / \mathrm{ha}$ in mid-season (11 April to 31 July), and 5,937-6,442 kg DM/ha in autumn (August to December). The farms producing the greatest quantity of herbage are achieving an extra grazing per year compared to the farms producing the least $(7.7$ and 6.8 grazings/paddock per year, respectively). There is a strong relationship between the number of grazings per year and herbage DM production. The extra grazing results in more grass in the diet of grazing livestock, reducing the requirement of supplement, and providing an extra 20 grazing days per year.

\section{Grass-clover systems}

Forage legumes, and white clover (Trifolium repens L.) in particular, have the potential to positively influence the sustainability of pasture-based ruminant production systems. There is increased interest in the use of clover in Ireland because it offers opportunities for sustainable pasture-based production systems. A recent meta-analysis (Dineen et al., 2017) was undertaken to quantify the milk production response associated with the introduction of clover into perennial ryegrass swards. The analysis found that at a mean sward clover content of $31.6 \%$, mean daily milk and MS yield per cow were significantly increased by 1.4 and $0.12 \mathrm{~kg}$, respectively, compared to grass only but there was no significant effect on milk yield and MS yield per ha. Within this analysis stocking rate and $\mathrm{N}$ fertilizer application were reduced by

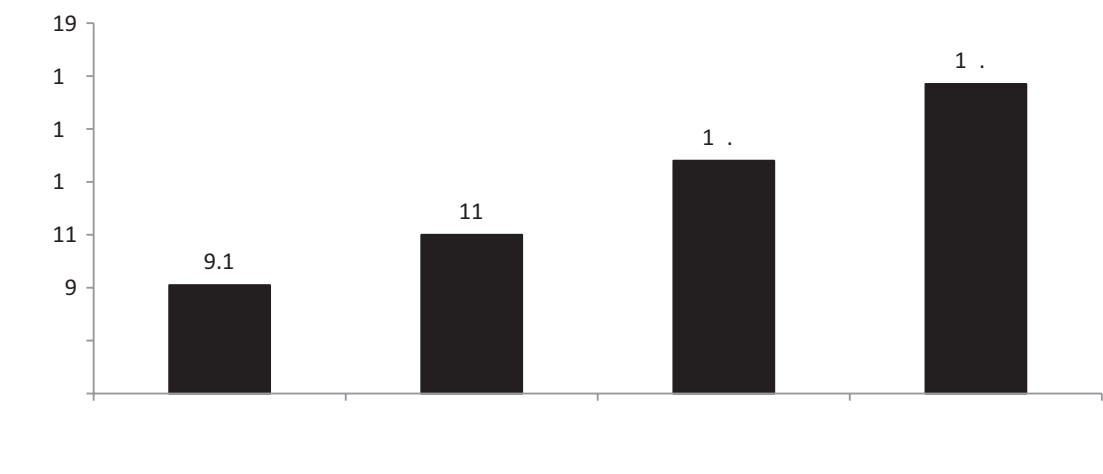

Figure 4. Average herbage DM production (t DM/ha) of national average dairy farms and farms in the bottom $20 \%$, average and top $20 \%$ recording into PastureBase Ireland. 
$0.25 \mathrm{cows} / \mathrm{ha}$ and $81 \mathrm{~kg} / \mathrm{ha}$, respectively, on grass-clover (3.32 cows/ha) swards compared with grass only (3.57 cows/ha) swards.

The most recent grass-clover research undertaken in Ireland at Teagasc Moorepark and Clonakilty has shown clear advantages of combining perennial ryegrass and clover compared to perennial ryegrass only. Dineen (2017) over a $2 \mathrm{yr}$ period, reported that, at the same stocking rate $(2.75 \mathrm{cows} / \mathrm{ha})$ and $\mathrm{N}$ fertiliser application rate $(250 \mathrm{~kg} \mathrm{~N} / \mathrm{ha}$ ), cows grazing grass-clover produced an additional $647 \mathrm{~kg}$ of milk and 55 $\mathrm{kg}$ MS per cow, compared to cows grazing grass only, which equated to an additional $1,781 \mathrm{~kg}$ milk and $151 \mathrm{~kg} \mathrm{MS} / \mathrm{ha}$. Total herbage DM production was $2.5 \mathrm{t} \mathrm{DM} /$ ha greater on grass-clover swards compared to grass-only swards. That experiment is being undertaken for a further $3 \mathrm{yr}$ to determine if those differences persist over time. Another farm systems experiment was undertaken at Teagasc, Moorepark, Ireland from 2013 to 2016. The experiment compared herbage and milk production from a grass-only sward receiving $250 \mathrm{~kg} \mathrm{~N} / \mathrm{ha}$ per year and grass-clover swards receiving 250 or $150 \mathrm{~kg}$ $\mathrm{N} /$ ha per year (Hennessy et al., 2017). Each treatment was stocked at 2.74 cows/ha. Annual herbage DM production was similar on all treatments (14.6 t DM/ha) across the $4 \mathrm{yr}$ of the experiment. Average annual sward clover content was greater on grass-clover receiving $150 \mathrm{~kg} \mathrm{~N} / \mathrm{ha}(27 \%)$ compared with grass-clover receiving $250 \mathrm{~kg} \mathrm{~N} / \mathrm{ha}(23 \%)$. MS yield was greater on the two grass-clover treatments $(495 \mathrm{~kg}$ $\mathrm{MS} / \mathrm{cow}$ per year, respectively) compared with the grass-only treatment (460 kg MS/cow per year).

\section{Improved delivery from grass breeding and evaluation systems}

Perennial ryegrass forms the basis of grassland production in Ireland and is the most important forage grass. Over $95 \%$ $(3,624 \mathrm{t})$ of all seed sold in Ireland is perennial ryegrass, and $4 \%(140 t)$ is white clover. There has been large plant breeding industry investment in producing new varieties and independent testing systems designed to identify and list those with the most improved performances over the past $40 \mathrm{yr}$. In Ireland, McDonagh et al. (2016) compared the DM yield and sward density of new grass varieties submitted for evaluation from 1973 to 2013, and grass digestibility of grass varieties from 1980 to 2013, under conservation and simulated grazing managements. DM yields showed an overall significant $(P<$ 0.001 ) average annual increase of $0.52 \%$ under conservation and $0.35 \%$ under simulated grazing, with similar levels of gain within maturity groups and ploidies. These rates were not constant over time, and periods of no gain occurred in various variety groupings. Sward density did not change significantly in the study period. Herbage digestibility showed no improvement over the timeframe but had the largest differences between concurrent varieties, indicating that improvements were possible in the future. The study indicated that plant breeding gains were primarily DM yield focused with sward density remaining stagnant over the $40 \mathrm{yr}$, while the lack of grass digestibility improvement appeared to only require more time to overcome.

McDonagh et al. (2016) have shown that perennial ryegrass breeders have achieved low increases in DM yield production over time. Given that the recognition of digestibility improvement was only relatively recently introduced to the testing system, further advances will need to be realised. The introduction of the Pasture Profit Index (PPI, McEvoy et al., 2011; O'Donovan et al., 2017) into the Irish Recommended List for Grass and Clover, combined with the change to evaluation under intensive simulated grazing protocols and more on farm grass and clover variety evaluation using PastureBase Ireland will bridge the gap between farmers, evaluation and breeding. Although there is a general consensus amongst breeders internationally that individual varieties can perform well in a range of environments, in fact the evidence from the PPI and the Irish Recommended List for Grass and Clover clearly shows that the best performing breeding programs for Ireland are those based in Ireland and the United Kingdom. It is likely that this trend will only become more obvious as a result of the development of the PPI given Ireland's huge dependence on grazed pasture. The grass varieties of choice in Ireland into the future grass will be those with high levels of graze out - ultimately these varieties will require better sward canopy characteristics. New focus on the development of a clover profit index for white clover breeding and evaluation will put more focus on the development of clovers for grazing systems, it may drive a change in clover breeding leading to high seasonal contributions from clover, which is required. There is also a requirement for grazing red clovers to be bred, little success as yet as been recorded on grazing red clovers although some New Zealand programmes are well into this development. With clover, whether it is white or red clover, the long-term persistence in the sward continues to be a huge challenge. Future grass and clover breeding and evaluation in Ireland will be designed to satisfy the end demands of the grassland farmer.

\section{Future direction and focus}

The success of Irish grass-based production systems is very dependent on five main challenges:

i. Continued adoption at farm level of improved grassland management practises and grassland technologies, much of the new focus will be on better nutrient management and ensuring a better agronomic return for chemical and organic fertiliser inputs 
ii. Focussed research on grazing management to optimise herbage DM production, quality and utilisation, as well as development of grassland management tools to facilitate improved grassland management practises

iii. Requirement to develop and maintain high clover proportions in grazing and conservation swards

iv. Ensure farm sustainability is improved and optimised with grassland as the main feed

v. Ensure that livestock farmers maintain efficient low costhigh grass-based systems

vi. Ireland is well placed to make further increases in grassland production; Irish farmers are keen adopters of grassland technology.

Ireland has successfully maintained the ethos of developing the family farm through sustainable grassland production; the Irish future success depends on improving this standard further.

\section{References}

Buckley, C., Donnellan, T., Dillon, E., Hanrahan, K., Moran, B. and Ryan, M. 2019. Teagasc national survey 2017 sustainability report produced March $26^{\text {th }}$ 2019. ISBN: 978-1-84170-650-4.

CSO. 2017. Central Statistics Office. Available online: https://cso. ie/en/statistics/agriculture/areayieldandproductionofcrops/ [Accessed May 2019].

DAFM. 2015. Department of Agriculture, Food and the Marine Food Wise 2025. Available online: www.agriculture.gov.ie/media/ migration/agrifoodindustry/foodwise2025/report/FoodWise2025. pdf [Accessed 1 September 2019].

DAFM. 2016. Fact Sheet on Irish Agriculture. Available online: https://www.agriculture.gov.ie/media/migration/publications/2016/ FactsheetIrishAgriculture180117290517.pdf [Accessed May 2019].

Dineen, M. 2017. Impact of Lolium perenne L. ploidy and Trifolium repens $\mathrm{L}$. inclusion in grazing swards, on herbage dry matter and milk production of spring calving dairy cattle. Master's thesis, Queen's University Belfast.

Dineen, M., Delaby, L., Gilliland, T.J. and McCarthy, B. 2017. Metaanalysis of the impact of white clover inclusion in perennial ryegrass swards on milk production. Journal of Dairy Science 101: 1804-1816.

Earle, E., McHugh, N., Boland, T.M. and Creighton, P. 2017. Evaluation of the effects of ewe prolificacy and stocking rate on herbage production, utilization, quality and sward morphology in a temperate grazing system. Grass and Forage Science 73: 247-256.

Finneran, E., Crosson, P., O'Kiely, P., Shalloo, L., Forristal, D. and Wallace, M. 2010. Simulation modelling of the cost of producing and utilising feeds for ruminants on Irish farms. Journal of Farm Management 14: 95-116.
Hanrahan, L., Geoghegan, A., O'Donovan, M., Ruelle, E., Wallace, M. and Shalloo, L. 2017. PastureBase Ireland: a grassland decision support system and national database. Computers and Electronics in Agriculture 136: 193-201.

Hennessy, D., McAuliffe, S., Hurley, M. and Egan, M. 2017. Moorepark update: herbage production and milk production from grass only and grass clover swards. Proceedings of the Moorepark '17 Open Day: Irish Dairying; Resilient Technologies, Teagasc Moorepark, Ireland, pages 41-42.

ICBF. 2016. Irish Cattle Breeding Federation. Available online: https:// www.icbf.com/wp/?p=6410 [Accessed May 2019].

McAuliffe, S. 2020. White clover inclusion in intensive dairy production systems. PhD Thesis, Queens University Belfast.

McCarthy, B., Pierce, K.M., Delaby, L., Brennan, A., Fleming, C. and Horan, B. 2012. The effect of stocking rate and calving date on grass production, utilization and nutritive value of the sward during the grazing season. Grass and Forage Science 68: 364-377.

McDonagh, J., O'Donovan, M., McEvoy, M. and Gilliland, T.J. 2016. Genetic gain in perennial ryegrass (Lolium perenne) varieties 1973 to 2013. EUPHYTICA 212: 187-199.

McEvoy, M., O'Donovan, M. and Shalloo, L. 2011. Development and application of an economic ranking index for perennial ryegrass cultivars. Journal of Dairy Science 94: 1627-1639.

O'Brien, D., Moran, B., Lanigan, G. and Shalloo, L. 2017. The declining carbon footpring of milk from Irish dairy farms. Proceedings of the Moorepark '17 Open Day: Irish Dairying; Resilient Technologies, Teagasc Moorepark, Ireland, pages 115-116.

O'Donovan, M., Lewis, E. and O'Kiely, P. 2011. Requirements of future grass-based ruminant production systems in Ireland. Irish Journal of Agriculture and Food Research 50: 1-21.

O'Donovan, M., Kelly, P. and O'Leary, M. 2016. Increasing grass utilisation on beef farms. Proceedings of the Beef Open Day, Teagasc Grange, Ireland, pages 32-37.

O'Donovan, M., McHugh, N., McEvoy, M., Grogan, D. and Shalloo, L. 2017. Combining seasonal yield, silage dry matter yield, quality and persistency in an economic index to assist perennial ryegrass variety selection. Journal of Agricultural Science 155: $556-568$.

O'Mara, F.P. 2008. Country Pasture/Forage Resource Profile/Ireland. The Food and Agriculture Organization of the United Nations. Available online: http://www.fao.org/ag/AGP/AGPC/doc/pasture/ forage.htm.

Teagasc. 2016a. Teagasc Dairy Roadmaps. Available online: www. teagasc.ie/publications/2016/road-map-2025-dairy.php.

Teagasc. 2016b. Teagasc National Farm survey. Available online: www.teagasc.ie/media/website/publications/2016/Dairy-2015.pdf.

Wall, D. and Dillon, E. 2017. Fertiliser Association of Ireland Workshop, Kildalton College. May 4th 2017. Available online: https://www. teagasc.ie/media/website/crops/soil-and-soil-fertility/Wall-Dillon-etal-Fert-Use-Survey_FAI-Kildalton-2017.pdf [Accessed 1 September 2019], 37 pages. 